\title{
Animal performance and carcass characteristics of Nellore young bulls fed coated or uncoated urea slaughtered at different weights
}

\author{
Raul Dirceu Pazdiora1, Flávio Dutra de Resende ${ }^{1,2}$, Marcelo Henrique de Faria², Gustavo \\ Rezende Siqueira ${ }^{1,2}$, Geraldo Benedito de Souza Almeida ${ }^{1}$, Ricardo Linhares Sampaio ${ }^{1}$, Paulo \\ Santana Pacheco ${ }^{3}$, Murilo Sergio Rodrigues Prietto ${ }^{4}$
}

\author{
${ }^{1}$ Programa de Pós-Graduação em Zootecnia, UNESP/FCAV- Jaboticabal/SP, Brazil. \\ ${ }^{2}$ APTA - Pólo Regional da Alta Mogiana (Colina/SP, Brazil). \\ ${ }^{3}$ Departamento de Zootecnia - Universidade Federal de Santa Maria. \\ ${ }^{4}$ Acadêmico de Zootecnia - UNIFEB - Barretos/SP, Brazil.
}

\begin{abstract}
The objective of this study was to evaluate animal performance and carcass characteristics of 64 Nellore young bulls at 22 months of age finished in a feedlot and slaughtered at five body weights $(350 ; 455 ; 485 ; 555$ and $580 \mathrm{~kg})$ fed diets containing coated or uncoated urea. The experimental design adopted was completely randomized, set in a $4 \times 2$ factorial arrangement, and for the variables assessed in the control animals, it was $5 \times 2$. No effect of interaction between slaughter weights and diets were observed, so the variables were analyzed separately, compared by polynomial contrasts and by the F test, respectively. The time animals remained in the feedlot to reach slaughter weights was $66,88,145$ and 194 days. Average daily gain (ADG) showed quadratic behavior, with a maximum of $1.44 \mathrm{~kg} /$ day with animals of $491.7 \mathrm{~kg}$. Dry matter intake (DMI) (kg/day) was similar in all the treatments, but it decreased linearly as body weight increased. The bionutritional efficiency worsened linearly as body weight rose. The elevation in slaughter weight resulted in linear decrease in the percentage of beef round and increase in forequarter. Backfat thickness and rib eye area of the longissimus increased linearly and the percentages of muscle and protein in the carcass reduced and those of fat and ether extract increased linearly as body weight increased. Average daily gain, DMI, feed efficiency and carcass characteristics were not affected by diets containing coated or uncoated urea. However, animals fed coated urea presenter better crude fiber and neutral detergent fiber intake.
\end{abstract}

Key Words: body composition, fat thickness, feed efficiency, feedlot, gain yield, high grain rations

\section{Introduction}

The feedlot is an alternative utilized by some farmers for finishing cattle. However, the period of confinement can vary according to factors like sex, breed group and the concentrate:roughage ratio. A longer period of confinement implicates higher production cost due to the worsening in feed conversion. In high grain diets ingested by ruminants, the evaluation of the nutritional value is a key point, and it has been a challenge for nutritionists. In the last few years, products that aim at the control of the release of non-protein nitrogen (NPN) in the rumen have been developed so as to improve the efficiency of transformation of nitrogen into microbial protein (Akay et al., 2004). According to Santos et al. (2011), the replacement of feeds that contain true protein by feeds with a higher content of non-protein nitrogen, such as urea, can improve the financial efficiency of feeding and reduce the need to purchase protein contents. Moreover, it allows for the formulation of diets with greater inclusion of energy feeds, fibrous by-products and forages.
The weight at slaughter is an important factor for cattle, once it has a direct effect on the animal response, affecting feed intake and animal performance, carcass characteristics and meat quality. Thus, determining the ideal slaughter weight for animals that meets the requirements of the commercialization and distribution systems is essential, once slaughterhouses prefer heavier animals and those with adequate fat degree, which is not interesting to the farmer, who needs more time for animals to stay in confinement, which may have a direct effect on productive and economic efficiency (Costa et al., 2002a; Restle et al., 2007). When slaughterhouses adopt bonus programs, the uniformity of the animals; sex; age; fat cover; and weight at slaughter are criteria utilized for a differentiated remuneration. Among these, one of the main factors is carcass weights, because this characteristic is correlated to boneless yield and standardization of the meat cuts.

The objective of this study was to evaluate the effect of slaughter weight on animal performance and the carcass 
characteristics of Nellore young bulls finished in a feedlot and fed high grain rations containing coated or uncoated urea.

\section{Material and Methods}

This experiment was carried out at Pólo Regional de Desenvolvimento Tecnológico dos Agronegócios da Alta Mogiana, located in the municipality of Colina, São Paulo State, Brazil, pertaining to Agência Paulista de Tecnologia dos Agronegócios (APTA).

Sixty-four Nellore young bulls at 22 months of age were used in this study. Animals were confined in individual semi-covered $10 \mathrm{~m}^{2}$ pens provided with individual feeders and drinkers.

The treatments consisted of five slaughter weights: 350 , $455,485,555$ and $580 \mathrm{~kg}$ body weight and two diets with urea: coated or uncoated. The coated urea was from the commercial brand Optigen ${ }^{\circledR}$ (Alltech). For each treatment, the number of animals (replications) was different. For the group slaughtered at 455 and $485 \mathrm{~kg}$, eight animals were utilized for the diet without coated urea (wCU) and seven for the diet with coated urea (WCU). For the animals slaughtered at $555 \mathrm{~kg}$, seven animals were used for each diet; and for $580 \mathrm{~kg}$, eight animals for wCU and six for WCU (Table 1).

Six animals from the group of slaughter weight at $350 \mathrm{~kg}$ (adopted as reference), representing the batch, were slaughtered at $348.5 \mathrm{~kg}$ body weight on the twenty-third day of adaptation. However, when the evaluation period started, the other animals weighed $363 \mathrm{~kg}$.

Diets were formulated so as to meet the requirements for an average daily gain (ADG) of $1.5 \mathrm{~kg}$ (NRC, 1996), using diet-formulation software Ração de Lucro Máximo (RLM, version 3.0) (Table 2). Feed was supplied twice daily: $50 \%$ in the morning (08h00) and $50 \%$ in the afternoon (14h00), keeping orts at around $10 \%$ of the amount supplied.

Table 1 - Distribution of animals by slaughter weight $(\mathrm{kg})$ and utilization of coated urea

\begin{tabular}{|c|c|}
\hline Slaughter weight & Diet \\
\hline 350 (6 animals) & --- \\
\hline 455 (15 animals) & $\begin{array}{c}\text { With coated urea ( } 7 \text { animals) } \\
\text { Without coated urea ( } 8 \text { animals) }\end{array}$ \\
\hline 485 (15 animals) & $\begin{array}{c}\text { With coated urea ( } 7 \text { animals) } \\
\text { Without coated urea ( } 8 \text { animals) }\end{array}$ \\
\hline 555 (14 animals) & $\begin{array}{c}\text { With coated urea ( } 7 \text { animals) } \\
\text { Without coated urea ( } 7 \text { animals) }\end{array}$ \\
\hline 580 (14 animals) & $\begin{array}{c}\text { With coated urea (6 animals) } \\
\text { Without coated urea ( } 8 \text { animals) }\end{array}$ \\
\hline
\end{tabular}

The adaptation of animals to the diet was restricted, gradually increasing the amount of feed, starting at $1 \%$ of the body weight on the first three days and increasing $0.2 \%$ at every three days, until the twenty-first day. Afterwards, feed was supplied ad libitum until the twenty-eighth day. Next, the evaluation period started at different days according to the slaughter weights desired. Animals were weighed after solid- and liquid-food deprivation of 16 hours.

Dry matter intake (DMI) per animal was determined by the amount of feed supplied minus orts, expressed in $\mathrm{kg}$ /day in relation to body weight (DMIBW), and feed conversion (FC), by the ratio between DMI and ADG.

To obtain the bionutritional efficiency values, variables ADG and DMI were considered together in a bivariate analysis, utilizing procedure MANOVA of software SAS (Statistical Analysis System, version 9.0). To complement the analysis, the first canonical discriminant function was used; according to Harris (1975), it results in higher value for the $\mathrm{F}$ test, considering any linear combination involving the variables analyzed. Bionutritional efficiency was determined from the coefficients generated by the analysis of the first canonical variable, forming the following equation: coefficient of bionutritional efficiency $=6.2172 *(\mathrm{ADG})$ $-0.4836^{*}$ (DMI). The least efficient animals were those which presented lowest bionutritional efficiency, because the canonical coefficient associated with gain was positive and the coefficient associated with intake was negative. Comparisons between the values obtained by the first canonical discriminant function were made via regression analysis.

Samples of ingredients of feeds and orts were collected three times a week and transformed in composite samples per animal at every 28 -day period. These were pre-dried in a forced air circulation oven at $55 \pm 5^{\circ} \mathrm{C}$ for 72 hours, then ground in a mill with $1 \mathrm{~mm}$ diameter pore sieve and stored for subsequent analyses. Percentages of dry matter (DM), crude protein $(\mathrm{CP})$, neutral detergent fiber (NDF), ether extract (EE), organic matter (OM) and ash were determined according to the analytical procedures described by the AOAC (1995). The total digestible nutrient (TDN) content was calculated according to Weiss et al. (1992).

Total weight gain was obtained by the difference between slaughter weight and the initial weight of evaluation. Average daily gain was the result of total body weight gain in relation to the total days the animal remained in confinement.

Hot carcass dressing (HCD) was the ratio between the body weight of the animal on the previous day and hot carcass weight. Total carcass gain was determined by the 
equation: (slaughter weight $\times \mathrm{CD})-($ initial weight $\times \mathrm{iCD})$. For initial carcass dressing (iCD), $52.9 \mathrm{~kg} / 100 \mathrm{~kg}$ body weight was used, determined by the slaughter of reference animals. The average daily gain in carcass was expressed considering the number of days the animal remained confined as well as its relation with ADG. The number of days animals remained in feedlot varied from 66 to 194 according to the slaughter weights intended.

The slaughter of animals was performed at slaughterhouse JBS Friboi, $20 \mathrm{~km}$ away from the feedlot, following the normal flow of the establishment (Brasil, 1971). During slaughter, the liver and the kidney-pelvic fat were collected for determination of weight. At the end of the slaughter line, carcasses were divided in two halves and weighed, resulting in hot carcass weight (HCW) and then taken to a cold chamber for 24 hours at a temperature of $0-4{ }^{\circ} \mathrm{C}$. After cooling down, carcasses were weighed, thus obtaining cold carcass weight (CCW). Shrinkage loss was determined by the difference between HCW and CCW. The right half-carcass was separated in prime cuts: forequarter, between the fifth and sixth ribs; short ribs or back ribs; and beef round or hindquarter.

A cut was made between the 12 th and 13 th ribs on the left half-carcass so as to expose the longissimus muscle to determine the longissimus muscle area (REA) and backfat thickness (BFT), as described by Müller (1987).

Carcass length, hindquarter length and cushion thickness were measured on the right half-carcass, according to Müller (1987). The carcass compactness index was determined by the ratio between $\mathrm{CCW}$ and carcass length. Fat cover degree was determined by a score ranging from 0 to 4 , where $0=$ absent; $1=$ scarce; $2=$ medium; $3=$ uniform; and $4=$ excess, according to Luchiari Filho (2000). The conformation, relating the muscle expression in the hindquarter, was determined by scoring from 1 to 5 , as follows: $1=$ convex; $2=$ sub-convex; $3=$ rectilinear; $4=$ sub-rectilinear; and $5=$ concave, according to Luchiari Filho (2000).
For determination of the carcass physical composition in muscle, fat and bone, a piece corresponding to the 9-10-11th ribs (HH section) of the cold left half-carcass was extracted, according to the methodology proposed by Hankins \& Howe (1946), according to the equations: muscle $=15.56+0.81(\mathrm{MHH})$; fat $=3.06+0.82(\mathrm{FHH})$ and bone $=4.30+0.61(\mathrm{BHH})$; where $\mathrm{MHH}, \mathrm{FHH}$ and $\mathrm{BHH}$ are the percentages of muscle, fat and bone, respectively, obtained from the $\mathrm{HH}$ equation. The $\mathrm{HH}$ section was analyzed for evaluation of chemical composition in relation to moisture, ash, crude protein and ether extract, according to the analytical procedures described by the AOAC (1995).

The experimental design adopted was completely randomized, set in a factorial arrangement, considering the effects of diet (with and without coated urea - 1 degree of freedom, DF), slaughter weights (455; 485; 555 and $580 \mathrm{~kg}-3 \mathrm{DF}$ ) and the interaction between diets and slaughter weights (3 DF) and the residue as having 50 DF. However, for the variables assessed on the reference animals, the factorial arrangement was $2 \times 4+1$ (diets $\times$ slaughter weights + reference slaughter), because reference animals slaughtered at the beginning of the experiment did not undergo any treatment. Firstly, the data were subjected to normality test, by the Shapiro-Wilk test; on the variables which did not present normality (ADG and FC), logarithmic transformation was performed. The data were subjected to variance analysis of statistical software SAS (Statistical Analysis System, version 9.0; 2002), utilizing procedure MIXED. The interaction effects were tested and analyzed, but they were not significant in any variable, so the main effects were discussed. When significant by the $\mathrm{F}$ test, the effect of slaughter weights was decomposed in 3 orthogonal contrasts: linear, quadratic and cubic. Since the slaughter weights were not equidistant, procedure PROC IML of SAS (9.0) was used to determine the coefficients of the contrasts. The effect of diets was analyzed by the $\mathrm{F}$ test. Significance for slaughter weights and for diets was

Table 2 - Composition of the diet utilized for feeding experimental animals

\begin{tabular}{|c|c|c|c|c|c|c|c|}
\hline \multirow[b]{2}{*}{ Diets } & \multicolumn{7}{|c|}{ Diet composition, $\mathrm{g} / \mathrm{kg}$ dry matter } \\
\hline & $\begin{array}{c}\text { Raw sugarcane } \\
\text { bagasse }\end{array}$ & Corn grain & Cottonseed & Soybean meal & Urea & Coated urea & Mineral mixture $^{1}$ \\
\hline Diet without coated urea & 130.0 & 674.2 & 99.4 & 50.0 & 12.5 & 0.00 & 33.9 \\
\hline \multirow[t]{2}{*}{ Diet with coated urea } & 200.0 & 584.2 & 99.4 & 70.0 & 2.50 & 10.0 & 33.9 \\
\hline & \multicolumn{7}{|c|}{ Bromatological composition, $\mathrm{g} / \mathrm{kg}$ dry matter } \\
\hline Diets & Dry matter & Mineral matter & Crude protein & Ether extract & $\begin{array}{l}\text { Neutral detergent } \\
\text { fiber }\end{array}$ & $\begin{array}{c}\text { Acid detergent } \\
\text { fiber }\end{array}$ & $\begin{array}{c}\text { Total digestible } \\
\text { nutrients }^{2}\end{array}$ \\
\hline Diet without coated urea & 814.7 & 75.4 & 140.7 & 55.4 & 242.6 & 143.4 & 682.4 \\
\hline Diet with coated urea & 802.5 & 83.2 & 141.7 & 54.9 & 302.4 & 187.2 & 687.8 \\
\hline
\end{tabular}

${ }^{1}$ Composition per kg of product: vitamin A - $78000 \mathrm{IU}$; vitamin D3 - $9750 \mathrm{IU}$; vitamin E - $325 \mathrm{IU}$; calcium - $160 \mathrm{~g}$; phosphorus - $18.75 \mathrm{~g}$; sodium - $62.5 \mathrm{~g}$; potassium - 50 g; magnesium - 15 g; sulfur - 25 g; manganese - 780 mg; zinc - 1875 mg; copper - 390 mg; cobalt - 23.6 mg; iodine - 23.6 mg; selenium - 6.5 mg; sodium monensin - 780 mg. ${ }^{2}$ Estimated by the equation of Weiss et al. (1992). 
declared $\mathrm{P}<0.05$. Pearson's correlation was utilized to determine the correlation between DMI with nutrient intake and BFT with physical and chemical composition.

\section{Results and Discussion}

There was no effect of interaction between slaughter weights and diets. Therefore, slaughter weights and diets were analyzed, presented and discussed separately.

Dry matter intake (kg/day) was similar for the animals slaughtered at the different weights. However, when DMI was expressed as ratio of body weight (DMIBW), there was a linear decrease for the heavier animals (Table 3). The data found in the literature about DMI according to slaughter weight are contradictory. Bailey et al. (1985), Galvão et al. (1991), Jorge et al. (1997) and Mello (2007) observed increases in DMI, expressed in $\mathrm{kg} /$ day, of diets as the slaughter weight increased, whereas Van Koevering et al. (1995), Costa et al. (2002a), Arboitte et al. (2004a) and Cruz et al. (2004a) did not observe any alteration. This demonstrates that there is variation in ingestion and that other factors, such as genetics, weight at maturity and type of diet, can interfere with this parameter. Reduction in DMIBW between the slaughter weight from 400 to 480 for animals of different genetic groups was reported by Cruz et al. (2004a). However, Mello (2007) did not observe difference for DMIBW when slaughtering crossbred Red Angus or Blonde D’Aquitaine with Nellore at 480, 520 and $560 \mathrm{~kg}$ body weight.

As for the evaluation of diets with and without coated urea, no differences were observed for DMI and DMIBW, showing averages of $8.66 \mathrm{~kg}$ and $19.7 \mathrm{~g} / \mathrm{kg}$ body weight, respectively. Evaluating coated urea $\left(\right.$ Optigen $\left.^{\circledR}\right)$ in diets for steers at the growth and finishing phases, Tedeschi et al. (2002) also did not find differences for DMI and DMIBW in relation to the diet containing urea.
The increase in slaughter weight did not affect nutrient intake. The similarity in the ingestion of nutrients is due to the similarity of DMI over the confinement period, since there were $(\mathrm{P}<0.0001)$ correlations between $\mathrm{DMI}$ and $\mathrm{OM}$ intake $(r=0.99)$, CP intake $(r=0.95)$, EE intake $(r=0.86)$, NDF intake $(r=0.84)$ and TDN intake $(r=0.99)$.

Feed conversion (FC) worsened as the slaughter weight increased, corroborating the literature (Costa et al., 2002a; Arboitte et al., 2004a; Cruz et al., 2004a). Costa et al. (2002a) reported that with increase in animal weight feed efficiency is lowered, and this is due to the differences in the composition of weight gain. With the increases in slaughter weight, there is an augmentation in the proportion of adipose tissue in gain in relation to the other tissues. Fat has a caloric value 2.25 times higher than protein and the fat deposition in the tissues is usually followed by reduction in the water content, which worsens even more the efficiency of weight gain (Cruz et al., 2004a). Feed conversion is the most important characteristic from the practical point of view, since it is characterized by the ratio between what is spent in the form of feed and what is returned in the form of weight gain.

The association of intake and gain, denominated bionutritional efficiency by Euclides Filho et al. (2001), results in a more efficient value to evaluate animal performance. Bionutritional efficiency (Table 3) decreased linearly with increase in body weight, confirming FC, wherein animals slaughtered at a higher weight are less efficient. However, many are the results found in the literature evaluating slaughter weight, breed group, feeding level and types of diet, in which no differences are found for FC; nevertheless, analyzing the bionutritional efficiency, some differences can be verified (Euclides Filho et al., 2001; Euclides Filho et al., 2003; Detmann et al., 2005; Mello, 2007). According to Detmann et al. (2005), bionutritional efficiency ensures maximum discrimination between

Table 3 - Feed intake and feed efficiency of Nellore young bulls fed diets with or without coated urea slaughtered at different weights

\begin{tabular}{|c|c|c|c|c|c|c|c|c|c|c|c|c|}
\hline \multirow{2}{*}{ Variables } & \multicolumn{4}{|c|}{ Slaughter weight (SW), kg } & \multicolumn{2}{|c|}{ Diets (D) } & \multirow{2}{*}{ CV (\%) } & \multicolumn{5}{|c|}{ P-value } \\
\hline & 455 & 485 & 555 & 580 & WCU & wCU & & $\mathrm{SW} \times \mathrm{D}$ & Linear & Quadratic & Cubic & $\mathrm{D}$ \\
\hline DMI & 8.76 & 8.80 & 8.68 & 8.40 & 8.77 & 8.55 & 9.69 & 0.688 & 0.234 & 0.450 & 0.775 & 0.339 \\
\hline DMIBW & 21.3 & 20.8 & 18.8 & 17.7 & 19.9 & 19.5 & 7.88 & 0.530 & 0.000 & 0.349 & 0.826 & 0.348 \\
\hline OMI & 8.27 & 8.29 & 8.14 & 7.84 & 8.19 & 8.09 & 9.71 & 0.732 & 0.147 & 0.442 & 0.750 & 0.655 \\
\hline CPI & 1.23 & 1.24 & 1.19 & 1.16 & 1.25 & 1.16 & 10.5 & 0.713 & 0.064 & 0.534 & 0.801 & 0.007 \\
\hline EEI & 0.74 & 0.77 & 0.75 & 0.75 & 0.75 & 0.76 & 11.7 & 0.858 & 0.934 & 0.431 & 0.662 & 0.715 \\
\hline NDFI & 2.81 & 2.75 & 2.72 & 2.66 & 2.95 & 2.51 & 11.1 & 0.794 & 0.217 & 0.969 & 0.672 & 0.000 \\
\hline TDNI & 6.04 & 5.99 & 5.89 & 5.70 & 5.98 & 5.84 & 9.91 & 0.741 & 0.123 & 0.660 & 0.711 & 0.438 \\
\hline $\mathrm{FC}$ & 6.44 & 6.28 & 6.63 & 7.58 & 6.81 & 6.64 & 6.44 & 0.358 & 0.000 & 0.020 & 0.363 & 0.433 \\
\hline BNE & 4.68 & 4.54 & 3.98 & 2.92 & 3.93 & 4.13 & 22.8 & 0.635 & 0.000 & 0.063 & 0.224 & 0.424 \\
\hline
\end{tabular}

$\mathrm{CV}$ - coefficient of variation; WCU - diet with coated urea; wCU - diet without coated urea.

DMI - dry matter intake (kg/day/animal); DMIBW - dry matter intake in relation to body weight (g/kg body weight); OMI - organic matter intake (kg/day); CPI - crude protein intake (kg/day); EEI - ether extract intake (kg/day); NDFI - neutral detergent fiber intake (kg/day); TDNI - total digestible nutrient intake (kg/day); FC - feed conversion; BNE - bionutritional efficiency.

Equations: DMIBW $=34.55741-0.02867 \mathrm{SW}\left(\mathrm{r}^{2}=0.48\right) ; \mathrm{FC}=2.37771+0.00833 \mathrm{SW}\left(\mathrm{r}^{2}=0.18\right) ; \mathrm{BNE}=10.55297-0.01256 \mathrm{SW}\left(\mathrm{r}^{2}=0.32\right)$ 
experimental groups and allows for the identification of non-perceivable differences of intensity and production characteristics, associated with the application of bionutritional efficiency.

As for the evaluation of efficiency and ingestion of nutrients in relation to the diets with urea, coated or not, no differences were observed $(\mathrm{P}>0.05)$ for $\mathrm{FC}$, bionutritional efficiency and daily intakes of OM, EE and TDN. Tedeschi et al. (2002), evaluating coated urea (Optigen $\left.{ }^{\circledR}\right)$ in diets for Aberdeen Angus steers in the growth and finishing phase, also did not find differences for $\mathrm{FC}$ in relation to the diet containing urea. However, animals receiving a diet containing coated urea obtained greater $(\mathrm{P}<0.05)$ intakes of $\mathrm{CP}$ and NDF than animals not receiving coated urea, presenting an average intake of $1.25 \mathrm{vs} .1 .16 \mathrm{~kg}$ and $2.95 \mathrm{vs} .2 .51 \mathrm{~kg}$, respectively. This higher NDF intake was because the composition of the diet presented more raw sugarcane bagasse, which contains a high percentage of this component.

The time animals remained confined, in days, varied according to the pre-determined slaughter weight (Table 4). The values were 66, 88, 145 and 194 days, respectively. Total body weight gain increased linearly as slaughter weight rose.

Average daily gain showed quadratic behavior, in which the peak was obtained when animals reached $491.7 \mathrm{~kg}$ body weight, presenting $1.44 \mathrm{~kg}$ /day (Table 3). With this slaughter weight, the estimated FC was $6.5 \mathrm{~kg} \mathrm{DM}$ ingested $/ \mathrm{kg}$ of gain. Arboitte et al. (2004a) verified that ADG decreased linearly as slaughter weight increased. This deceleration in weight gain in the final stage of confinement can be suggested mainly as being a result of the greater energy requirement for maintenance and composition of gain (NRC, 1996), wherein the proportion of fat tissue in gain increases along with the body weight and proportional reduction in DMI, and consequently, the higher the body weight, the lower the DMIBW. The ratio of dry matter intake by body weight limited animal performance, mainly at the heavier slaughter weights $(555$ and $580 \mathrm{~kg}$ ). The lower DMIBW was insufficient to keep ADG, which rose until $491.7 \mathrm{~kg}$ and subsequently reduced until the highest slaughter weight $(580 \mathrm{~kg})$.

Final weight and total body weight gain were not affected by the type of diet, presenting averages of 519.5 and $156 \mathrm{~kg}$, respectively, which reflected the similar ADG, with an average of $1.31 \mathrm{~kg}$. Tedeschi et al. (2002), evaluating coated urea $\left(\right.$ Optigen $\left.{ }^{\circledR}\right)$ in diets for finishing Aberdeen Angus steers also did not find differences for the $\mathrm{ADG}$ in the diet containing urea.

The gain in carcass per day, expressed in $\mathrm{kg}$, decreased linearly. However, when expressed as a ratio of body weight gain it presented quadratic behavior with increase in the slaughter weight of animals, in which the minimum was obtained when animals presented $506.7 \mathrm{~kg}$ (Table 4). This demonstrates that there is a tendency to increase in the percentage of body weight gain, which is converted in carcass with increase in animal weight. Mello (2007) found 95,79 and $79 \%$ in the carcass gain:weight gain ratio of animals slaughtered at 480,520 and $560 \mathrm{~kg}$, but without significant differences. The similarity in the carcass gain: weight gain ratio and the high value found can be a result of the underestimation, by these authors, of the initial carcass dressing (CD) of $50 \%$ for confined animals.

Similarity for the animals fed the diets was also verified $(\mathrm{P}>0.05)$ for daily carcass gain and gain yield, with averages of 0.81 and $61.9 \mathrm{~g}$ carcass gain/100 g body weight gain, respectively.

Hot and cold carcass weights (Table 5) increased linearly $(\mathrm{P}<0.05)$ along with increase in the body weight of animals, as a consequence of the weight gain associated with increase in $\mathrm{CD}$. Heavier carcasses are more and more requested by slaughterhouses, because they reduce operational costs, in addition to providing heavier meat cuts.

Table 4 - Days in feedlot, body weight, body weight gain, carcass gain and carcass dressing gain of Nellore young bulls fed diets with or without coated urea slaughtered at different weights

\begin{tabular}{|c|c|c|c|c|c|c|c|c|c|c|c|c|}
\hline \multirow{2}{*}{ Variables } & \multicolumn{4}{|c|}{ Slaughter weight (SW), kg } & \multicolumn{2}{|c|}{ Diets (D) } & \multirow{2}{*}{ CV $(\%)$} & \multicolumn{5}{|c|}{ P-value } \\
\hline & 455 & 485 & 555 & 580 & WCU & $\mathrm{wCU}$ & & $\mathrm{SW} \times \mathrm{D}$ & Linear & Quadratic & Cubic & D \\
\hline Days & 66 & 88 & 145 & 194 & - & - & - & - & - & - & - & - \\
\hline IW & 365 & 360 & 364 & 365 & 364 & 363 & 4.46 & 0.881 & 0.746 & 0.470 & 0.642 & 0.673 \\
\hline FW & 457 & 485 & 555 & 583 & 520 & 519 & 5.02 & 0.820 & 0.000 & 0.702 & 0.931 & 0.834 \\
\hline TBWG & 92 & 124 & 191 & 218 & 156 & 156 & 13.3 & 0.651 & 0.000 & 0.930 & 0.634 & 0.945 \\
\hline ADG & 1.35 & 1.41 & 1.31 & 1.22 & 1.31 & 1.31 & 55.4 & 0.289 & 0.000 & 0.015 & 0.340 & 0.987 \\
\hline ADCG & 0.88 & 0.83 & 0.80 & 0.72 & 0.80 & 0.82 & 14.1 & 0.072 & 0.000 & 0.554 & 0.176 & 0.483 \\
\hline DRESS & 64.0 & 58.7 & 61.2 & 63.7 & 61.0 & 62.8 & 9.39 & 0.394 & 0.709 & 0.010 & 0.410 & 0.254 \\
\hline
\end{tabular}

$\mathrm{CV}$ - coefficient of variation; WCU - diet with coated urea; wCU - diet without coated urea.

IW - initial weight (kg); FW - final weight (kg); TBWG - body weight gain (kg); ADG - average daily gain (kg/day); ADCG - average daily carcass gain (kg/day); DRESS - carcass dressing gain ( $\mathrm{g}$ gain in carcass $/ 100 \mathrm{~g}$ gain in body weight).

Equations: $\mathrm{FW}=-3.36804+1.00841 \mathrm{SW}\left(\mathrm{r}^{2}=0.81\right) ; \mathrm{TBWG}=-358.53810+0.99250 \mathrm{SW}\left(\mathrm{r}^{2}=0.87\right) ; \mathrm{ADG}=-8.03611+0.03856 \mathrm{SW}-0.00003921 \mathrm{SW}{ }^{2}\left(\mathrm{R}^{2}=0.28\right) ;$ $\mathrm{ADCG}=-232.695+0.635 \mathrm{SW}\left(\mathrm{r}^{2}=0.18\right) ; \mathrm{DRESS}=309.85144-0.99147 \mathrm{SW}+0.0009784 \mathrm{SW}^{2}\left(\mathrm{R}^{2}=0.12\right)$. 
The increase in body weight of animals at slaughter rose CD linearly. These results are similar to those obtained by Galvão et al. (1991), Mello (2007) and Restle et al. (1997), who stated that the lower CD obtained in lighter animals is due to the greater relative weight of hides, paws and head, and also as a consequence of the more advanced fat cover of heavier animals, resulting in greater deposition of fat in the carcass. Even in a short period of confinement (66 days) animals already produced carcasses that meet the minimum required by slaughterhouses $(225 \mathrm{~kg})$.

Hot and cold carcass weights and carcass dressing did not differ between the animals which received diets with or without coated urea. This similarity in the carcass can be attributed to the similar initial weight and ADG among the animals that received the diets (Table 4), promoting same slaughter weight. Working with Aberdeen Angus steers in the finishing phase, Tedeschi et al. (2002) did not find differences in relation to the carcass containing urea.

The increase in slaughter weight (Table 5) resulted in linear decrease in the percentage of beef round in relation to the carcass, wherein each additional kilogram resulted in a reduction of $0.022 \mathrm{~kg} / 100 \mathrm{~kg}$ hindquarter carcass. For the forequarter, the result observed was the opposite, in which the increase in animal body weight at slaughter elevated the percentage of forequarter in the carcass. Costa et al. (2002b) found decrease in the percentage of hindquarter in relation to carcass weight, with increase in slaughter weight from 340 to 370,400 or $430 \mathrm{~kg}$, also in accordance with the results found by Galvão et al. (1991), who also observed reduction in the percentage of hindquarter with increased slaughter weight. However, Jorge et al. (1999) did not find differences in the percentages of beef round with increase in slaughter weight from 500 to $550 \mathrm{~kg}$ for crossbred animals and from 450 to $500 \mathrm{~kg}$ for Nellore animals.

The differences in percentage of hind- and forequarter might also have occurred by the sexual dimorphism of uncastrated animals, in which there is a more accelerated muscle development of the forequarter. This fact might not be advantageous for the slaughterhouse, once the meat cuts of highest commercial value (sirloin, tenderloin and full rump) are located in the hindquarter. However, the percentage of these cuts in relation to the cold carcass weight remained similar with increase in body weight, presenting an average value of $11.2 \%$. This fact demonstrates that the slaughterhouse can benefit from having heavier carcasses.

At the evaluation of carcass weight, it is desirable that the proportion of beef round be superior to $48 \mathrm{~kg} / 100 \mathrm{~kg}$ carcass, forequarter up to $39 \mathrm{~kg} / 100 \mathrm{~kg}$ carcass and short ribs up to $13 \mathrm{~kg} / 100 \mathrm{~kg}$ carcass (Luchiari Filho, 2000), given the location of the noble cuts of highest commercial value. In this study, the percentage of beef round was inferior to $48 \mathrm{~kg} / 100 \mathrm{~kg}$ carcass in the animals with body weight higher than $517 \mathrm{~kg}$. However, the percentage of forequarter in the animals slaughtered between 350 and $580 \mathrm{~kg}$ was always above $39 \mathrm{~kg} / 100 \mathrm{~kg}$ carcass, probably because animals presented sexual dimorphism with greater development of the forequarter, especially of the hump, for being Nellore (Bos taurus indicus) animals; brisket and short ribs remained lower than $13 \mathrm{~kg} / 100 \mathrm{~kg}$ carcass.

As to the prime cuts yield, animals presented similarity $(\mathrm{P}>0.05)$ in the cuts among the diets, which was expected, since the diet has little direct effect on these cuts and there are other factors that present greater importance for the alteration in the proportion of commercial cuts, such as slaughter weight, age, sex and breed group.

Backfat thickness (BFT) and fat cover degree increased linearly along with the body weight of animals (Table 6), which is in line with the reports found in the literature (Galvão et al., 1991; Restle et al., 1997; Leme et al., 2000; Kuss et al., 2005), wherein we observe an increase of 0.028 $\mathrm{mm}$ BFT for each increase in body weight. The fat cover in the carcass is important, because it reduces the losses by dehydration during cooling. Besides, it also avoids external darkening of the muscles that cover the carcass, providing better visual aspect and preventing the quick cooling of the carcass and shortening of the muscle fibers due to the cold. The bonus programs for carcasses implanted in most exporting slaughterhouses require a minimum of $6.0 \mathrm{~mm}$ BFT, e.g., the program of reward for carcasses of Angus animals (Group Marfrig, 2012). With the results obtained (Table 6), this value would be reached with a body weight at slaughter of $537.5 \mathrm{~kg}$, which is equivalent to $300.9 \mathrm{~kg}$ hot carcass, with an estimated beef round and forequarter yields of 47.3 and $41.9 \mathrm{~kg} / 100 \mathrm{~kg}$ carcass, respectively.

The loss by cooling (shrinkage loss) decreased linearly as slaughter weight increased, due to the smaller loss of liquid during cooling caused by the greater fat content in the carcass. In general, carcasses with better fat cover degree present lower loss during cooling, resulting in negative correlation between the two variables, according to the results published by Restle et al. (1997) and Arboitte et al. (2004b) and the present study, presenting significant correlation $(\mathrm{r}=-0.45)$. According to Restle et al. (1997), the variation in shrinkage loss is also associated with the oscillations that occur in the cold chamber (temperature, wind speed, number of carcasses). In the present study, although all slaughters were performed in the same slaughterhouse, they took place at different dates, so there might have been variations in the environment of the cold chamber. 
Backfat thickness (Table 6), expressed in $100 \mathrm{~kg}$ cold carcass, increased linearly with elevation in body weight. According to Arboitte et al. (2004b), this result reflects the intensification of the fat deposition process as the animals reach adult weight. However, Restle et al. (1997) reported that in order to reach the desired fat cover degree, animals must be fed for a longer period, since fat cover is a tissue of late deposition and increases proportionally with the age and weight of cattle.

Kidney-pelvic fat, in $\mathrm{kg}$ and in percentage of $\mathrm{CCW}$ and body weight, rose linearly along with increased body weight (Table 6). The internal fats are important indicators of body fat deposition. Leme et al. (2000) evaluated different breed groups slaughtered at three weights, and verified increase in the sum of kidney, pelvic and inguinal fats, both in $\mathrm{kg}$ and percentage of carcass, with increased slaughter weight (448, 493 and $515 \mathrm{~kg}$ ), finding 6.1, 8.4 and $10.4 \mathrm{~kg}$; and 2.6, 3.2 and $3.7 \%$, respectively.
The results obtained for absolute liver weight and in relation to $\mathrm{CCW}$ and slaughter weight (Table 6) were similar to those published by Kuss et al. (2007), who slaughtered cows at 465, 507 and $566 \mathrm{~kg}$ and observed that the weight of the liver was superior for animals slaughtered at 507 and $566 \mathrm{~kg}$ in relation to those at $465 \mathrm{~kg}$. When the authors analyzed it in percentage of empty body, they verified reduction for the animals slaughtered at a heavier weight. These authors suggested that the greater rate of body mass deposition may require more synthesis of nutrients from the liver for the formation of tissues. According to Owens et al. (1993) and Ferrel \& Jenkins (1998), of the vital organs, the liver has the highest metabolic rates, because of its important participation in the nutrient metabolism; it is also directly related to nutrient intake. These authors verified in their study that DMI and weight of the liver, expressed as percentage of body weight, decreased linearly with increased slaughter weight.

Table 5 - Carcass characteristics of Nellore young bulls fed diets with or without coated urea slaughtered at different weights

\begin{tabular}{|c|c|c|c|c|c|c|c|c|c|c|c|c|c|}
\hline \multirow{2}{*}{ Variables } & \multicolumn{5}{|c|}{ Slaughter weight (SW), kg } & \multicolumn{2}{|c|}{ Diets (D) } & \multirow{2}{*}{$\mathrm{CV}(\%)$} & \multicolumn{5}{|c|}{ P-value } \\
\hline & 350 & 455 & 485 & 555 & 580 & WCU & $\mathrm{wCU}$ & & $\mathrm{SW} \times \mathrm{D}$ & Linear & Quadratic & Lack of fit & $\mathrm{D}$ \\
\hline $\mathrm{HCW}, \mathrm{kg}$ & 184 & 251 & 264 & 309 & 331 & 267 & 269 & 5.5 & 0.513 & 0.000 & 0.492 & 0.683 & 0.598 \\
\hline $\mathrm{CCW}, \mathrm{kg}$ & 179 & 248 & 260 & 305 & 327 & 263 & 265 & 5.5 & 0.602 & 0.000 & 0.647 & 0.116 & 0.521 \\
\hline $\mathrm{CD}$ & 52.8 & 54.9 & 54.4 & 55.7 & 56.8 & 54.7 & 55.2 & 2.3 & 0.209 & 0.000 & 0.594 & 0.354 & 0.092 \\
\hline HIND & 51.6 & 49.1 & 48.4 & 46.7 & 46.4 & 48.5 & 48.5 & 2.5 & 0.630 & 0.000 & 0.748 & 0.737 & 0.908 \\
\hline FORE & 40.4 & 40.2 & 41.0 & 42.1 & 42.9 & 41.4 & 41.3 & 2.8 & 0.811 & 0.000 & 0.004 & 0.584 & 0.785 \\
\hline SRIB & 8.0 & 10.6 & 10.6 & 11.0 & 10.7 & 10.1 & 10.2 & 6.0 & 0.626 & 0.000 & 0.000 & 0.700 & 0.462 \\
\hline
\end{tabular}

$\mathrm{CV}$ - coefficient of variation; WCU - diet with coated urea; wCU - diet without coated urea.

HCW - hot carcass weight; CCW - cold carcass weight; CD - carcass dressing (kg carcass/100 kg body weight); HIND - hindquarter or beef round (kg/100 kg carcass); FORE forequarter $(\mathrm{kg} / 100 \mathrm{~kg}$ carcass $)$; SRIB - short-ribs or back ribs $(\mathrm{kg} / 100 \mathrm{~kg}$ carcass $)$.

Equations: $\mathrm{HCW}=-38.62727+0.63173 \mathrm{SW}\left(\mathrm{r}^{2}=0.90\right) ; \mathrm{CCW}=-42.73877+0.63196 \mathrm{SW}\left(\mathrm{r}^{2}=0.90\right) ; \mathrm{CD}=47.36287+0.01570 \mathrm{SW}\left(\mathrm{r}^{2}=0.40\right) ; \mathrm{HIND}=59.37885-0.02253 * \mathrm{SW}$ $\left(\mathrm{r}^{2}=0.64\right) ; \mathrm{FORE}=34.64091+0.01358 * \mathrm{SW}\left(\mathrm{r}^{2}=0.38\right) ; \mathrm{SRIB}=5.98141+0.00894 * \mathrm{SW}\left(\mathrm{r}^{2}=0.38\right)$.

Table 6 - Backfat thickness (BFT), backfat in relation to cold carcass weight (BFT CCW), carcass dressing (DRES), shrinkage loss (SL) and weights of kidney-pelvic fat and liver of Nellore young bulls fed diets with or without coated urea slaughtered at different weights

\begin{tabular}{|c|c|c|c|c|c|c|c|c|c|c|c|c|c|}
\hline \multirow{2}{*}{ Variables } & \multicolumn{5}{|c|}{ Slaughter weight (SW), kg } & \multicolumn{2}{|c|}{ Diets (D) } & \multirow{2}{*}{$\mathrm{CV}(\%)$} & \multicolumn{5}{|c|}{ P-value } \\
\hline & 350 & 455 & 485 & 555 & 580 & WCU & wCU & & $\mathrm{SW} \times \mathrm{D}$ & Linear & Quadratic & Lack of fit & $\mathrm{D}$ \\
\hline $\mathrm{BFT}, \mathrm{mm}$ & 0.58 & 3.91 & 4.30 & 5.75 & 7.83 & 4.46 & 4.48 & 26.3 & 0.787 & 0.000 & 0.667 & 0.431 & 0.939 \\
\hline BFT_CCW ${ }^{1}$ & 0.32 & 1.58 & 1.68 & 1.89 & 2.39 & 1.56 & 1.58 & 26.9 & 0.533 & 0.000 & 0.093 & 0.188 & 0.926 \\
\hline $\mathrm{DRES}^{2}$ & 0.33 & 1.60 & 1.85 & 2.28 & 2.62 & 1.68 & 1.80 & 31.5 & 0.755 & 0.000 & 0.240 & 0.444 & 0.455 \\
\hline $\mathrm{SL}^{3}$ & 2.75 & 1.40 & 1.35 & 1.40 & 1.25 & 1.72 & 1.55 & 28.3 & 0.431 & 0.000 & 0.000 & 0.121 & 0.219 \\
\hline $\mathrm{KPF}$ & 1.73 & 4.75 & 5.66 & 7.97 & 9.58 & 5.82 & 6.05 & 22.9 & 0.639 & 0.000 & 0.203 & 0.358 & 0.561 \\
\hline $\mathrm{KPF} \_\mathrm{HCW}$ & 0.93 & 1.89 & 2.14 & 2.58 & 2.88 & 2.05 & 2.11 & 20.5 & 0.643 & 0.000 & 0.612 & 0.534 & 0.606 \\
\hline KPF_BW & 0.49 & 1.04 & 1.16 & 1.43 & 1.64 & 1.13 & 1.18 & 20.6 & 0.568 & 0.000 & 0.847 & 0.376 & 0.507 \\
\hline LIV & 3.93 & 5.31 & 5.51 & 5.44 & 5.52 & 5.15 & 5.13 & 10.3 & 0.626 & 0.000 & 0.000 & 0.511 & 0.897 \\
\hline LIV_CCW & 2.12 & 2.11 & 2.08 & 1.76 & 1.66 & 1.95 & 1.94 & 8.0 & 0.607 & 0.000 & 0.000 & 0.785 & 0.716 \\
\hline LIV_BW & 1.12 & 1.16 & 1.14 & 0.98 & 0.94 & 1.07 & 1.07 & 7.5 & 0.408 & 0.000 & 0.000 & 0.345 & 0.941 \\
\hline
\end{tabular}

$\mathrm{CV}$ - coefficient of variation; WCU - diet with coated urea; wCU - diet without coated urea.

$\mathrm{KPF}$ - kidney-pelvic fat (kg); KPF HCW - kidney-pelvic fat in relation to hot carcass weight ( $\mathrm{kg} / 100 \mathrm{~kg}$ hot carcass); KPF BW- kidney-pelvic fat in relation to body weight ( $\mathrm{kg} / 100 \mathrm{~kg}$ body weight); LIV - liver weight ( $\mathrm{kg}$ ); LIV CCW - liver in relation to cold carcass weight (kg/100 kg hot carcass weight); LIV BW - liver in relation to body weight (kg/100 kg body weight).

Equations: $\mathrm{BFT}=-9.42533+0.0287 \mathrm{SW}\left(\mathrm{r}^{2}=0.70\right) ; \mathrm{BFT} C \mathrm{CW}=-2.02779+0.00750 \mathrm{SW}\left(\mathrm{r}^{2}=0.55\right) ; \mathrm{DRES}=-2.66063+0.00914 \mathrm{SW}\left(\mathrm{r}^{2}=0.54\right) ; \mathrm{SL}=3.74800-0.00452 \mathrm{SW}$ $\left(r^{2}=0.25\right) ; \mathrm{KPF}=-10.76351+0.03435 \mathrm{SW}\left(\mathrm{r}^{2}=0.73\right) ; \mathrm{KPF}$ CAR $=-1.84539+0.00813 \mathrm{SW}\left(\mathrm{r}^{2}=0.62\right) ; \mathrm{KPF} B W=-1.16404+0.00479 \mathrm{SW}\left(\mathrm{r}^{2}=0.64\right) ; \mathrm{LIV}=2.78273+0.00503 \mathrm{SW}$ $\left(r^{2}=0.25\right) ; \mathrm{LIV} H C W=3.22255-0.00257 \mathrm{SW}\left(\mathrm{r}^{2}=0.51\right) ; \mathrm{LIV} B W=-0.48303+0.00790 \mathrm{SW}-0.00000942 \mathrm{SW}^{2}\left(\mathrm{R}^{2}=0.59\right)$.

${ }_{1}^{1} \mathrm{~mm} / 100 \mathrm{~kg}$ cold carcass.

${ }^{2}$ Score: $0=$ absent, $1=$ scarce, $2=$ medium, $3=$ uniform, $4=$ excess.

${ }^{3} \mathrm{~kg} / 100 \mathrm{~kg}$ carcass. 
Animals receiving diets with or without coated urea showed similarity in the amount of kidney-pelvic fat and liver in absolute weight and also in relation to $\mathrm{HCW}$ and body weight. Tedeschi et al. (2002) evaluated coated urea $\left(\right.$ Optigen $\left.^{\circledR}\right)$ in diets for steers in the finishing phase and did not find differences in relation to the diet containing urea for BFT and kidney-pelvic-heart fat, either.

Carcass length and depth increased linearly along with slaughter weight (Table 7), which demonstrates that animals were still under body growth. The regression equation indicates that for every additional kilogram at slaughter there was an increase of 0.075 and $0.037 \mathrm{~cm}$ in carcass length and depth, respectively. This behavior was reported by Costa et al. (2002b) and Restle et al. (1997), working with growing animals.

Other measures related to the muscle development of the carcass are cushion thickness and hindquarter length, which increased linearly along with slaughter weight. The estimates by the equation show that the increases were of 0.082 and $0.018 \mathrm{~cm}$, respectively, for each additional kilogram in the weight at slaughter. Cushion thickness was positively and significantly correlated $(\mathrm{P}<0.0001)$ with slaughter weights, hot and cold carcasses, beef round weight and carcass compactness index, presenting respective values of $0.87,0.90,0.90,0.93$ and 0.89 .

Concerning compactness index (Table 7), it increased linearly with elevation in slaughter weights. Through the estimate of the regression equation we can verify that the increase was of $0.003 \mathrm{~kg} / \mathrm{cm}$ for every additional kilogram in the slaughter weights of animals, i.e., more kilograms of carcass are deposited per centimeter.

The conformation, which measures the carcass muscle expression subjectively, rose linearly with increase in body weight. According to Müller (1987), carcasses with better conformation tend to present a lower percentage of bone and greater edible portion. Slaughtering animals at 425, 467 and $510 \mathrm{~kg}$, Arboitte et al. (2004a) did not verify differences in conformation with increase in weight. Costa et al. (2002b) verified significant correlations between conformation and the measures that evaluated the muscle development of the carcass, according to increase in body weight.

Rib eye area increased linearly as slaughter weight increased, which was similar to the results reported in the literature, in which increase in body weight at slaughter resulted in greater REA, both in late breeds, like Charolais (Restle et al., 1997); early breeds, like Aberdeen Angus (Costa et al., 2002b); crossings between various breeds (Cruz et al., 2004b); and Zebu breeds, like Gyr, Guzerat, Tabapuã and Nellore (Jorge et al., 1999). The rib eye area expressed in $100 \mathrm{~kg}$ cold carcass decreased with increase in body weight, agreeing with the results observed in the literature, demonstrating linear decrease from 27 to 24 and from 26.2 to $23.2 \mathrm{~cm}^{2} / 100 \mathrm{~kg}$ carcass, with increase in slaughter weight from 550 to 700 , in crossbred Blonde D'Aquitaine $\times$ Charolais (Patterson et al., 1994) and from 440 to $507 \mathrm{~kg}$ in crossbred Aberdeen Angus $\times$ Brahman (Huffman et al., 1990). According to Restle et al. (1997), the decrease is a consequence of the reduction in the level of muscle development as the weight of animals increases.

Carcass length and depth, cushion thickness, beef round length, carcass compactness index, conformation, REA and REA in relation to CCW did not differ $(\mathrm{P}>0.05)$ between the animals fed diets with or without coated urea.

The percentage of muscle in the carcass decreased linearly with increase in body weight at slaughter (Table 8). Of the carcass tissues, the muscle was predominant, but its participation decreased from 63.7 to $55.9 \mathrm{~kg} / 100 \mathrm{~kg}$ of carcass when slaughter weight was elevated from 350 to $580 \mathrm{~kg}$.

Table 7 - Metric measures and carcass conformation of Nellore young bulls fed diets with or without coated urea slaughtered at different weights

\begin{tabular}{|c|c|c|c|c|c|c|c|c|c|c|c|c|c|}
\hline \multirow{2}{*}{ Variables } & \multicolumn{5}{|c|}{ Slaughter weight (SW), kg } & \multicolumn{2}{|c|}{ Diets (D) } & \multirow{2}{*}{$\mathrm{CV}(\%)$} & \multicolumn{5}{|c|}{ P-value } \\
\hline & 350 & 455 & 485 & 555 & 580 & WCU & $\mathrm{wCU}$ & & $\mathrm{SW} \times \mathrm{D}$ & Linear & Quadratic & Lack of fit & $\mathrm{D}$ \\
\hline CARL & 128 & 136 & 139 & 144 & 146 & 139 & 138 & 2.3 & 0.966 & 0.000 & 0.770 & 0.383 & 0.164 \\
\hline CARD & 37.9 & 38.7 & 40.6 & 41.6 & 43.9 & 40.5 & 40.6 & 5.2 & 0.930 & 0.000 & 0.011 & 0.432 & 0.585 \\
\hline CUSTH & 97 & 108 & 109 & 115 & 117 & 109 & 110 & 2.4 & 0.352 & 0.000 & 0.415 & 0.110 & 0.216 \\
\hline HINDL & 86.8 & 86.3 & 85.4 & 88.1 & 90.2 & 87.9 & 86.8 & 2.9 & 0.797 & 0.012 & 0.001 & 0.159 & 0.130 \\
\hline CCI & 1.40 & 1.82 & 1.86 & 2.11 & 2.25 & 1.87 & 1.90 & 5.6 & 0.640 & 0.000 & 0.883 & 0.061 & 0.240 \\
\hline $\mathrm{CONF}^{1}$ & 1.83 & 2.72 & 3.15 & 3.57 & 3.81 & 3.08 & 2.95 & 22.3 & 0.354 & 0.000 & 0.729 & 0.844 & 0.477 \\
\hline REA & 52.8 & 64.9 & 65.5 & 72.0 & 76.7 & 65.5 & 67.2 & 12.0 & 0.182 & 0.000 & 0.968 & 0.300 & 0.444 \\
\hline REACCW & 29.5 & 26.1 & 25.2 & 23.6 & 23.4 & 25.5 & 25.7 & 9.9 & 0.253 & 0.000 & 0.368 & 0.787 & 0.749 \\
\hline
\end{tabular}

CV - coefficient of variation; WCU - diet with coated urea; wCU - diet without coated urea.

CARL - carcass length; CARD - carcass depth; CUSTH - cushion thickness; HINDL - hindquarter length; CCI - carcass compactness index; CONF - conformation; REA - rib eye area; REACCW - rib eye area in relation to cold carcass weight $\left(\mathrm{cm}^{2} / 100 \mathrm{~kg}\right.$ cold carcass).

Equations: $\mathrm{CARL}=101.87631+0.07599 \mathrm{SW}\left(\mathrm{r}^{2}=0.74\right) ; \mathrm{CARD}=26.64790+0.02808 \mathrm{SW}\left(\mathrm{r}^{2}=0.51\right) ; \mathrm{CUSTH}=69.27326+0.08247 \mathrm{SW}\left(\mathrm{r}^{2}=0.82\right) ; \mathrm{HINDL}=78.46491+0.01777 \mathrm{SW}$ $\left(r^{2}=0.16\right) ; C C I=0.17671+0.00354 S W\left(r^{2}=0.84\right) ; C O N F=-1.02407+0.00834 S W\left(r^{2}=0.41\right) ; R E A=18.68137+0.09858 S W\left(r^{2}=0.41\right) ; R E A C C W=37.76202-0.02526 S W$ $\left(\mathrm{r}^{2}=0.33\right)$.

${ }^{1}$ Score: $1=$ convex, $2=$ sub-convex, $3=$ rectilinear, $4=$ sub-rectilinear and $5=$ concave. 
Among the tissues that compose the carcass, the muscle is of highest commercial importance, for being the most desired by the consumer, in addition to presenting relevant nutritional importance, due to its adequate proportion of essential amino acids, lipids, vitamins and mineral salts for human nutrition (Arboitte et al., 2004c). Although the absolute weight of the bone tissue increased along with slaughter weight, its percentage participation decreased, as a consequence of increase in the weight of muscle and (especially) fat tissues, similarly to the results obtained by Galvão et al. (1991) and Restle et al. (1997).

The percentage of fat in the carcass was contrary to the muscle (Table 8), since this component increased along with elevation in the body weight of animals. Linear increase in the percentage of fat in the carcass with increased slaughter weight was reported by Galvão et al. (1991), Restle et al. (1997), Costa et al. (2002b) and Arboitte et al. (2004c). According to Berg \& Butterfield (1976), fat has its highest deposition increase at the most advanced developmental stage of the animal; Boggs \& Merkel (1979) ratified that during the growth phase, fat is the tissue that presents the latest development, but it is deposited at all ages provided the energy intake exceeds the requirement of maintenance and growth of the animal. The percentage of fat in the carcass followed the behavior of the variation in BFT, and the correlation between these two variables was highly elevated $(\mathrm{r}=0.73 ; \mathrm{P}<0.05)$.

During the confinement period, the physical components of the carcass, in absolute weight, increased by $39.0 \%$ for bone, $60.3 \%$ for muscles and $219.5 \%$ for fat, indicating that in the finishing phase, under the same nutritional conditions, the fat tissue is the most intensely deposited in the carcass. Evaluating the increase in the three tissues that compose the carcass, Costa et al. (2002b) verified that elevating the slaughter weight of Red Angus steers from 340 to 430 resulted in an increase of 24.1 and $23.8 \mathrm{~kg} / 100 \mathrm{~kg}$ carcass, respectively, in the muscle and bone weights, and $60.2 \mathrm{~kg} / 100 \mathrm{~kg}$ carcass in the fat weight.
The ratio between the amount of muscle and fat decreased as the body weight at slaughter increased, and this is due to the superiority of fat gain compared with the muscle, as previously reported. Reduction in muscle:fat ratio with increase in slaughter weight is reported in the studies of Galvão et al. (1991), Restle et al. (1997), Jorge et al. (1999), Costa et al. (2002b) and Arboitte et al. (2004c). However, the muscle + fat:bone ratio, representing the edible part, increased with elevation in body weight. Evaluating the influence of slaughter weight on the carcass characteristics of Red Angus steers, Costa et al. (2002b) verified similarity in the muscle:bone ratio (4.40) and quadratic effect in the muscle portion + fat:bone ratio, presenting maximum value of 6.47 in animals slaughtered at $395 \mathrm{~kg}$.

Regarding the diets, animals fed both coated and uncoated urea did not show similarity $(\mathrm{P}>0.05)$ in physical composition of the carcass. The similarity in these traits is related to the similarity in the other previously mentioned characteristics, such as slaughter weight, ADG and BFT.

The chemical composition of the $\mathrm{HH}$ section was modified as the body weight of animals increased (Table 9). The percentage of dry matter increased linearly with increase in body weight, as a consequence of the elevation in the percentage of EE, presenting a correlation $(\mathrm{P}<0.05)$ of 0.96 . Ether extract in the carcass rose from 8.84 to $28.9 \mathrm{~kg} / 100 \mathrm{~kg}$ carcass as body weight at slaughter rose from 350 to $580 \mathrm{~kg}$, following the same tendency of fat composition in the carcass $(r=0.92 ; \mathrm{P}<0.05)$. The percentages of mineral matter and crude protein reduced with increased slaughter weight, showing negative correlation $(\mathrm{P}<0.05)$ with the percentage of $E E(r=0.84$ and $r=0.46$, respectively), but in line with the decrease in percentage of muscle and bone in the carcass with increase in body weight. The chemical composition of the HH section has a high correlation with the body and carcass chemical compositions (Peron et al., 1993; Jorge et al., 2000), so further studies on nutrition should be conducted to evaluate feeds and animal growth.

Table 8 - Physical composition of the carcass of Nellore young bulls fed diets with or without coated urea and slaughtered at different weights

\begin{tabular}{|c|c|c|c|c|c|c|c|c|c|c|c|c|c|}
\hline \multirow{2}{*}{ Variables } & \multicolumn{5}{|c|}{ Slaughter weight (SW), kg } & \multicolumn{2}{|c|}{ Diets (D) } & \multirow{2}{*}{ CV $(\%)$} & \multicolumn{5}{|c|}{$\mathrm{P}$-value } \\
\hline & 350 & 455 & 485 & 555 & 580 & WCU & $\mathrm{wCU}$ & & $\mathrm{SW} \times \mathrm{D}$ & Linear & Quadratic & Lack of fit & $\mathrm{D}$ \\
\hline MUS & 63.7 & 59.9 & 56.6 & 54.8 & 55.9 & 58.6 & 57.8 & 4.9 & 0.870 & 0.000 & 0.137 & 0.072 & 0.256 \\
\hline FAT & 17.2 & 24.4 & 27.8 & 30.2 & 29.6 & 25.3 & 26.4 & 11.7 & 0.824 & 0.000 & 0.016 & 0.092 & 0.182 \\
\hline BONE & 19.0 & 15.7 & 15.6 & 14.9 & 14.2 & 15.8 & 15.8 & 6.0 & 0.508 & 0.000 & 0.000 & 0.296 & 0.947 \\
\hline $\mathrm{M}: \mathrm{F}$ & 3.72 & 2.53 & 2.06 & 1.84 & 1.92 & 2.51 & 2.32 & 16.0 & 0.594 & 0.000 & 0.000 & 0.102 & 0.064 \\
\hline $\mathrm{M}+\mathrm{F}: \mathrm{B}$ & 4.25 & 5.57 & 5.42 & 5.75 & 6.07 & 5.42 & 5.40 & 6.9 & 0.500 & 0.000 & 0.035 & 0.202 & 0.858 \\
\hline
\end{tabular}

$\mathrm{CV}$ - coefficient of variation; WCU - diet with coated urea; wCU - diet without coated urea.

MUS - muscle ( $\mathrm{kg} / 100 \mathrm{~kg}$ carcass); FAT - fat ( $\mathrm{kg} / 100 \mathrm{~kg}$ carcass); BONE - bone ( $\mathrm{kg} / 100 \mathrm{~kg}$ carcass); M:F - ratio between the amount of muscle and fat; M+F:B - ratio between the amount of muscle + fat and bone.

Equations: $\mathrm{MUS}=75.46674-0.03582 \mathrm{SW}\left(\mathrm{R}^{2}=0.42\right) ; \mathrm{FAT}=0.73504+0.05231 \mathrm{SW}\left(\mathrm{R}^{2}=0.54\right) ; \mathrm{BONE}=23.79435-0.01676 \mathrm{SW}\left(\mathrm{R}^{2}=0.54\right) ; \mathrm{M}: \mathrm{F}=5.82615-0.00714 \mathrm{SW}$ $\left(\mathrm{R}^{2}=0.58\right) ; \mathrm{M}+\mathrm{F}: \mathrm{B}=2.41037+0.00618 \mathrm{SW}\left(\mathrm{R}^{2}=0.52\right)$. 
Table 9 - Chemical composition of the Hankins \& Howe section (HH section) of Nellore young bulls fed diets with or without coated urea slaughtered at different weights

\begin{tabular}{|c|c|c|c|c|c|c|c|c|c|c|c|c|c|}
\hline \multirow{2}{*}{ Variables } & \multicolumn{5}{|c|}{ Slaughter weight (SW), kg } & \multicolumn{2}{|c|}{ Diets (D) } & \multirow{2}{*}{ CV $(\%)$} & \multicolumn{5}{|c|}{ P-value } \\
\hline & 350 & 455 & 485 & 555 & 580 & WCU & $\mathrm{wCU}$ & & $\mathrm{SW} \times \mathrm{D}$ & Linear & Quadratic & Lack of fit & $\mathrm{D}$ \\
\hline DM & 37.4 & 44.5 & 47.6 & 49.4 & 52.2 & 45.6 & 46.8 & 5.3 & 0.930 & 0.000 & 0.168 & 0.454 & 0.065 \\
\hline MM & 7.48 & 6.46 & 6.85 & 6.22 & 5.78 & 6.46 & 6.60 & 12.7 & 0.611 & 0.000 & 0.439 & 0.181 & 0.849 \\
\hline $\mathrm{CP}$ & 21.3 & 18.0 & 18.4 & 16.6 & 17.4 & 18.3 & 18.4 & 6.2 & 0.338 & 0.000 & 0.003 & 0.551 & 0.844 \\
\hline $\mathrm{EE}$ & 8.84 & 19.9 & 22.4 & 26.6 & 28.9 & 20.7 & 21.9 & 14.4 & 0.933 & 0.000 & 0.063 & 0.485 & 0.197 \\
\hline
\end{tabular}

CV - coefficient of variation; WCU - diet with coated urea; wCU - diet without coated urea; HH section: collected according to Hankins \& Howe (1946).

$\mathrm{DM}$ - dry matter (kg/100 kg carcass); MM - mineral matter (kg/100 kg carcass); CP - crude protein (kg/100 kg carcass); EE - ether extract (kg/100 kg carcass).

Equations: $\mathrm{DM}=17.76004+0.05903 \mathrm{SW}\left(\mathrm{r}^{2}=0.72\right) ; \mathrm{EE}=-17.72671+0.08108 \mathrm{SW}\left(\mathrm{r}^{2}=0.74\right) ; \mathrm{CP}=25.99336-0.01606 \mathrm{SW}\left(\mathrm{r}^{2}=0.44\right) ; \mathrm{MM}=9.49231-0.00598 \mathrm{SW}\left(\mathrm{r}^{2}=0.20\right)$

\section{Conclusions}

Nellore animals starting confinement at $360 \mathrm{~kg}$ body weight present their best performance when slaughtered at $491 \mathrm{~kg}$. Increasing slaughter weight worsens efficiency to transform feed into carcass; however, it improves the carcass fat cover. To obtain carcasses of uncastrated Nellore animals with a minimum of $6.0 \mathrm{~mm}$ backfat, the body weight at slaughter must be $537.5 \mathrm{~kg}$. The use of coated urea in high grain diets with 7\% more sugarcane bagasse and 9\% less corn grain promotes similar productive performance in uncastrated feedlot-finished Nellore animals.

\section{References}

AKAY, V.; TIKOFSKY, J.; HOLTZ, C. et al. Optigen ${ }^{\circledR} 1200$ : Controlled release of nonprotein nitrogen in the rúmen. In: INTERNATIONAL FEED INDUSTRY SYMPOSIUM, 20., 2004, Lexington. Proceedings... Lexington: Alltech, 2004. p.179-185.

ARBOITTE, M.Z.; RESTLE, J.; ALVES FILHO, D.C. et al. Desempenho em confinamento de novilhos 5/8 Nelore - 3/8 Charolês abatidos em diferentes estádios de desenvolvimento. Revista Brasileira de Zootecnia, v.33, n.4, p.947-958, 2004a.

ARBOITTE, M.Z.; RESTLE, J.; ALVES FILHO, D.C. et al. Características da carcaça de novilhos $5 / 8$ Nelore - 3/8 Charolês abatidos em diferentes estádios de desenvolvimento. Revista Brasileira de Zootecnia, v.33, n.4, p.969-977, 2004b.

ARBOITTE, M.Z.; RESTLE, J.; ALVES FILHO, D.C. et al. Composição física da carcaça, qualidade da carne e conteúdo de colesterol no músculo Longissimus dorsis de novilhos 5/8 Nelore 3/8 Charolês terminados em confinamento e abatidos em diferentes estádios de maturidade. Revista Brasileira de Zootecnia, v.33, n.4, p.959-968, 2004c.

ASSOCIATION OF OFFICIAL ANALYTICAL CHEMISTRY AOAC. Official methods of analysis. 16.ed. Arlington: AOAC International, 1995.

BAILEY, C.M.; LIBORIUSSEN, T.; ANDERSEN, H.R. et al. Producing beef from intact male progeny of Holstein sires: feed efficiency and compositional characters. Journal of Animal Science, v.61, n.1, p.27-35, 1985.

BERG, R.T.; BUTTERFIELD, R.M. New concepts of cattle growth. 1.ed. New York, 1976. 240p.

BOGGS, D.L.; MERKEL, R.A. Live animal, carcass evaluation and selection manual. Dubuque: Kendall/Hunt Publishing Company, 1979. 199p.

BRASIL. Ministério da Agricultura Pecuária e Abastecimento (1971). Normas de carne padronização de técnicas, instalações e equipamentos I - Bovinos, currais e anexos e sala de matança. Brasília, 1971.
COSTA, E.C.; RESTLE, J.; VAZ, F.N. et al. Desempenho de novilhos Red Angus superprecoce, confinados e abatido com diferentes pesos. Revista Brasileira de Zootecnia, v.31, n.1, p.129-138, 2002a.

COSTA, E.C.; RESTLE, J.; VAZ, F.N. et al. Características da carcaça de novilhos Red Angus superprecoces abatidos com diferentes pesos. Revista Brasileira de Zootecnia, v.31, n.1, p.119-128, 2002b.

CRUZ, G.M.; ESTEVES, S.N.; TULLIO, R.R. et al. Peso de abate de machos não-castrados para produção do bovino jovem. 1 . Desempenho em confinamento e custos de produção. Revista Brasileira de Zootecnia, v.33, n.3, p.635-645, 2004a.

CRUZ, G.M.; TULLIO, R.R.; ESTEVES, S.N. et al. Peso de abate de machos não-castrados para produção do bovino jovem. 2 . Peso, idade e características da carcaça. Revista Brasileira de Zootecnia, v.33, n.3, p.646-657, 2004b.

DETMANN, E.; CECON, P.R.; ANDREOTTI, M.O. et al. Application of the first canonical variable in the evaluation of animal production trials. Revista Brasileira de Zootecnia, v.34, n.6, p.2417-2426, 2005.

EUCLIDES FILHO, K.; EUCLIDES, V.P.B.; FIGUEIREDO, G.R. et al. Eficiência bionutricional de animais Nelore e seus mestiços com Simental e Aberdeen Angus, em duas dietas. Revista Brasileira de Zootecnia, v.30, n.1, p.77-82, 2001.

EUCLIDES FILHO, K.; FIGUEIREDO, G.R.; EUCLIDES, V.P.B. et al. Desempenho de diferentes grupos genéticos de bovinos de corte em confinamento. Revista Brasileira de Zootecnia, v.32, n.5, p.1114-1122, 2003

FERREL, C.L.; JENKINS, T.G. Body composition and energy utilization by steers of diverse genotypes fed a high-concentrate diet during the finishing period: Angus, Boran, Brahman, Hereford and Tuli Sires. Journal of Animal Science, v.76, n.2, p.647-657, 1998.

GALVÃO, J.G.; FONTES, C.A.A.; PIRES, C.C. et al. Características e composição da carcaça de bovinos não castrados, abatidos em três estágios de maturidade (estudo II) de três grupos raciais. Revista da Sociedade Brasileira de Zootecnia, v.20, n.5, p.502-512, 1991.

GRUPO MARFRIG (2012) Programa de premiação angus Marfrig. Available at: <http://www.marfrig.com.br/fomento/premiacoes/ programa-premiacao-angus/index.asp> Accessed on: Aug15, 2012.

HANKINS, O.G.; HOWE, P.E. Estimation of the composition of beef carcasses and cuts. Washington, D.C.: USDA, 1946. 21p. (Technical Bulletin, USDA, 926).

HARRIS, R.J. A primer of multivariate statistics. New York: Academic, 1975. 332p.

HUFFMAN, R.D.; WILLIAMS, S.E.; HARGROVE, D.D. et al Effects of percentage Brahman and Angus breeding, age-season of feeding and slaughter end point on feedlot performance and carcass characteristics. Journal of Animal Science, v.68, n.8, p.2243-2252, 1990.

JORGE, A.M.; FONTES, C.A.A.; FREITAS, J.A. et al. Ganho de peso e de carcaça, consumo e conversão alimentar de bovinos e bubalinos, abatidos em dois estágios de maturidade. Revista Brasileira de Zootecnia, v.26, n.4, p.806-812, 1997.

JORGE, A.M.; FONTES, C.A.A.; PAULINO, M.F. et al. Desempenho produtivo de animais de quatro Raças Zebuínas, abatidos em três estádios de maturidade. 2. Características da carcaça. Revista Brasileira de Zootecnia, v.28, n.1, p.381-387, 1999. 
JORGE, A.M.; FONTES, C.A.A.; PAULINO, M.F. et al. Utilização de método indireto para predição da composição química corporal de zebuínos. Revista Brasileira de Zootecnia, v.29, n.6, p.1862-1867, 2000.

KUSS, F.; BRONDANI, I.L.; PASCOAL, L.L. et al. Características da carcaça de vacas de descarte de diferentes grupos genéticos terminadas em confinamento com distintos pesos. Revista Brasileira de Zootecnia, v.34, n.3, p.915-925, 2005.

KUSS, F.; RESTLE, J.; BRONDANI, I.L. et al. Órgãos vitais e trato gastrintestinal de vacas de descarte mestiças Charolês - Nelore abatidas com pesos distintos. Revista Brasileira de Zootecnia, v.36, n.2, p.421-429, 2007.

LEME, P.R.; BOIN, C.; MARGARIDO, R.C.C. et al. Desempenho no confinamento e características da carcaça de bovinos machos de diferentes cruzamentos abatidos em três faixas de peso. Revista Brasileira de Zootecnia, v.29, n.6, p.2347-2353, 2000.

LUCHIARI FILHO, A. Pecuária da carne bovina. 1.ed. São Paulo: A. Luchiari Filho, 2000. 134p.

MELLO, R.O. Eficiência produtiva e econômica, características da carcaça e qualidade da carne de bovinos mestiços confinados e abatidos com diferentes pesos corporais. 2007. 147f. Tese (Doutorado em Zootecnia) - Universidade Federal de Viçosa, Viçosa, MG.

MÜLLER, L. Normas para avaliação de carcaças e concurso de carcaça de novilhos. 2.ed. Santa Maria: Universidade Federal de Santa Maria, 1987. 31p.

NATIONAL RESEARCH COUNCIL - NRC. Nutrient requeriments of beef cattle. 7.ed. rev. National Academy Press, Washington, D.C., 1996. 242p.

OWENS, F.N., DUBESKI, P., HANSON, C.F. Factors that alter the growth and development of ruminants. Journal of Animal Science, v.71, n.11, p.3138-3150, 1993.
PATTERSON, D.C.; MOORE, C.A.; STEEN, R.W.J. The effects of plane of nutrition and slaughter weight on the performance and carcass composition of continental beef bulls given high forage diets. Animal Production, v.58, n.1, p.41-47, 1994.

PERON, A.J.; FONTES, C.A.A.; LANA, R.P. et al. Tamanho dos órgãos internos e distribuição da gordura corporal em novilhos de cinco grupos genéticos, submetidos à alimentação restrita e ad libitum. Revista da Sociedade Brasileira de Zootecnia, v.22, n.5, p.813-819, 1993.

RESTLE, J.; KEPLIN, L.A.S.; VAZ, F.N. Características quantitativas da carcaça de novilhos Charolês, abatidos com diferentes pesos. Pesquisa Agropecuária Brasileira, n.8, v.32, p.851-856, 1997.

RESTLE, J.; PACHECO, P.S.; COSTA, E.C. et al. Apreciação econômica da terminação em confinamento de novilhos Red Angus superjovens, abatidos com diferentes pesos. Revista Brasileira de Zootecnia, v.34, n.4, p.978-986, 2007.

SANTOS, J.F.; DIAS JÚNIOR, G.S.; BITENCOURT, L.L. et al. Resposta de vacas leiteiras à substituição parcial de farelo de soja por ureia encapsulada. Arquivos Brasileiros de Medicina Veterinária e Zootecnia, v.36, n.2, p.423-432, 2011.

TEDESCHI, L.O.; BAKER, M.J.; KETCHEN, D.J. et al. Performance of growing and finishing cattle supplemented with a slow-release urea product and urea. Canadian Journal of Animal Science, v.82, p.567-573, 2002.

VAN KOEVERING, M.T.; GILL, D.R.; OWENS, F.N. et al. Effect of time on feed on performance of feedlot steers, carcass characteristics, and tenderness and composition of longissimus muscle. Journal of Animal Science, v.73, n.1, p.21-28, 1995.

WEISS, W.P.; CONRAD, H.R.; St. PIERRE, N.R. A theoreticallybased model for predicting total digestible nutrient values of forages and concentrates. Animal Feed Science and Technology, v.39, p. $95-110,1992$. 